\title{
ECOPRAXICALITY OF KUNITZIAN TEXT: ECOCONSCIOUSNESS DEVELOPMENT IN STANLEY KUNITZ'S SELECTED POEMS
}

\author{
Nidhal Muneam Mohammed, Prof. Saad Najim Al-Khafaji (PhD) \\ University of Baghdad - College of Education for Human Sciences - IbnRushd - Department of English
}

DOI: $10.37648 /$ ijrssh.v10i01.014

Received:15th October, 2019; Accepted:31 $1^{\text {st }}$ October, 2019; Published: 26th November, 2019

\begin{abstract}
By adopting ecocritical approach, this study aims at examining the neologism ecopraxis applicability to Stanley Kunitz's text in an attemptto investigate the poet's ecoconsciousness development. Ecocritically, this paper will try to explicate the environmental issues Kunitz's poetry implicates measuring his awareness extent of Man's devastating, unsustainable activities that threaten the planet balance and concluding whether his text proposes a sort of solution to encounter such problems, concerning both flora and fauna, that, in turn, proves his text's ecopraxicality.

Key words:kunitzian text, eco-issues, ecoconsciousness, ecopraxis, solution
\end{abstract}

\section{INTRODUCTION}

The spurring changes in the methods poets and other writers engage with the notion of nature, the environmental crisis has catalyzed the emergence of Ecocriticism. In the anthology The Ecocriticism Reader: Landmarks in literary Ecology (1996), edited by Cheryll Glotfelty and Harold Fromm, Cheryll Glotfelty, in her essay "Introduction: Literary Studies in an Age of Environmental Crisis", gives a concise statement about what is ecocricticism describing it as "the study of the relationship between literature and the physical environment" (xviii).The impact between literature and the physical environment is assumed to be interchangeable. Traditionally, nature is utilized as a means to exteriorize the poet's feelings and thoughts not as an end in itself. Recently, more aware of this close connection, critics are instigated to examine how it has been textualized by the writers in their works. From being merely a setting or a background to humans' concerns and interests, nature has become a case as much important as woman and race cases to enlighten readers of Man's unsustainable acts.

Trying to explicate the environmental issues implicated within the modern American poet Stanley Kuntiz's early and late poetry, the second phase of Cheryll Glotfelty's developmental ecocritical movement is adopted here. Michael J. McDowell, in his essay "The Bakhtinian Road to Ecological Insight," articulates that, in the second stage, ecocriticism attempts to "rediscover or recognize the tradition of nature writing in both neglected and celebrated writers; biographical criticism plays a strong role at this stage" (Gltofelty \& Fromm 383). This phase ecocritics examine issues of environmental justice and focusing on the necessity of developing a 'social ecocriticism' which takes seriously urban landscape as 'natural' landscape (Buell 22). Drawing attention to such issues works on raising an ecological awareness (Dobie 243). This stage is also known as 
'revisionist ecocriticism.' It tries to determine the remains of nature in cities and unmasks eco-unjustice crimes against the marginal section of the society. The ecocritics explicate nature texts and simultaneously "use them as a context for analyzing the principles and customs of our society in relationship to nature." Usually, the outcome is a critique of how human culture 'devalues' and 'degrades' the natural world (Mishra 168-9). This phase purport issimilar somehow to Scott Slovic's proclaim that the aim of ecocriticism is reinforcing ecological awareness and bringing about an ecological consciousness to the application of literary criticism (Oppermann 105). In addition to that, interlocked with those scholars' discussion, Lawrence Buell's supposition that literature-environment relevance study should be "conducted in a spirit of commitment environmentalist praxis," as Dana Phillips mentions in his essay "Ecocriticism, Literary Theory, and the Truth of Ecology" (583), leads us to coin a neologism called ecopraxis. Ecopraxical text, which does not have only theoreticality but practicality as well concerning environmental issues,provokes a possible solution to correct the contemporary environmental situation. Principally, ecocriticism began in consciousness-raising in an attempt to reach ecological sustainability as a conservation concept.

So, this paper aims at investigating Stanley Kunitz's poetry from ecocritical perspective focusing on his ecoconsciousness development. Although fascinated by depicting nature before being affected by technology, he is fully aware of war and Man's impact on it. The findings of the study will determine the neologism ecopraxis applicability to the Kunitzian text and its validity in suggesting a solution.

\section{KUNITZ'S EARLY POETRY: AN ECOCRITICAL READING}

Stanley Kunitz's “The War Against the Trees" is taken from a group of poems in his volumeSelected Poems 1928-1958 entitled as "The Terrible Threshold." Such title is probably so-named because its poems characterize different ways in which "humanity and the earth are on the brink of catastrophic change" (Thomason 215).

"The War Against the Trees", in which war is human-to-nature one, depicts a sample of a larger environmental problem which is deforestation and soil erosion. The text explicitly posits critically important problems in the modern world like the unsustainable use of natural resources due to growth and development and the problem of suburbanization or suburban sprawl.

As a witness, the speaker in the poem narrates the event of selling a lawn to an oil company. Laughingly, the owner invites his neighbors to watch the "show" of bulldozing his lawn. Demolished and distorted, nature is regarded as a victim of this war. Disharmony prevails man-nature relationship (Thomason 221). In his essay "The Historical Roots of Our Ecological Crisis", Lynn White, Jr. assures "man's relation to the soil was profoundly changed. Formerly man had been part of nature; now he was the exploiter of nature" (Glotfelty and Fromm 8). The overthrowing of trees, beginning with "privet-row," and digging the earth for oil exhibit nature as a victim of a rape crime. People are motivated by their rapacity for gasoline and the machines move towards unknown future.

The foolish human attack disfigures the landscape. The "Forsythia-forays and hydrangea-raids" were:

but preliminaries to a war of the town,

They struck and struck again, century went down. (8-12)
So freshly lopped and maimed.

Against the great-grandfathers

And with each elm a

Bulldozing is like "forays" and "raids" waged against old trees humanized as "the great-grandfathers." They embody human's history, heritage and past. By belonging to a particular place, Kunitz assumes the flora and fauna of that place become one's relatives (Thomason 226). Thus, by toppling the trees, they are actually removing a witness of their civilization history because with each elm gets "lopped," "a century went down." They are killing off part not just of nature but of one's self too.

Human beings are charged not only with their subverting trees by "Hacking" underground but with the horror their hacking ends up causing to the animals as well: 
dark summer's mole

Till a northern seizure shook giants to their knees. (15-18)
Rampages through his halls,

Those crowns, forcing the

Seemingly, the landscape is transformed into a stage of epic battle. The elms are compared to kings and giants that are "forced to their knees," and terrified, its panicked inhabitants, like the mole, run away. Setting the poem underground, through the metaphor "underground," is a denotation of the fundamentality of these trees to this place, to its ecosystem, to its very identity as a place (Thomason 226). Such war is an eradication of nature and humiliation of its inhabitants. Blindly pursuing his avidity, man's acts wind up in environmental crises, in extinction of certain sorts of plants and animals. Though the planet can be self-repaired somehow, the continual harmful, unsustainable activities of man do not give a chance for this repair to happen. Therefore, the planet and its ecosystem are in a, unnoticeably, slow deterioration.

Throughout the poem a sort of consciousness is raised toward significant issues concerning the environment health. ManNature relationship, in the poem, is proved to be pragmatic. All kinds of relations are monetized; everything has been commodified. Human beings look at nature as a sustained yield, but their acts are unsustainable. William Rueckert, in his essay "Literature and Ecology," asserts that:

we are in an environmental crisis because the means by which we use the ecosphere to produce wealth are destructive of the ecosystem itself. The present system of production is self-destructive. The present course of human civilization is suicidal. [. . .] Human beings have broken out of the circle of life, driven not by biological need, but by social organization which they have devised to conquer nature . . . (Glotfelty and Fromm 116)

Man's egocentricity and anthropocentricity blind him of seeing the subversive outcomes of his suicidal actions on his kind and home. The side effects of his activities surface on the long run. Standing on a neutral spot, the poet apparently characterizes how the suburban sprawl demolishes the natural world as a result of growth and development.

The poem is ecocentric text conscious of environmental issues whose discussion here affirms its writer's profound ecoconsciousness of them that happened and are still happening due to industrialization and technological progress. Man's suicidal and self-destructive deeds erase the past, devastate the present, and lead toward an unknown future.Kunitz wants to enflame the public consciousness of the serious consequences of man's egoistic and anthropocentric way of thinking in an attempt to eliminate or minimize his activities that may end up in a global environmental crisis. The poet, prophetically, warns of the future of this planet. Eventually, Man's beliefs and values are the cause of the nature desanctification. Faulty practices make the planet invalid place for living in the future. Sometimes, the culprit commits suicide by murdering others. Those bulldozers could be "all of us." Our unsustainable acts collectively cause a slow deterioration of the planet's ecosystem. Though neither Ecocriticism nor writing about environmental issues in literature make a direct contribution to determine policies, they play an active role in provoking people's consciousness concerning such ecological problems.

In addition to what has been accounted for above, Kunitz's "The Mulch" of his later poetry, from The-Testing-Tree (1971), demonstrates him more mature and experienced in the world around him instead of his inner world. It speaks about a man (the poet in disguise) works in his garden beside the sea trying to transform it from a barren land into a flowering one. Gregory Orr, in his Stanley Kunitz: An Introduction to the poetry (1985), confirms that Nature and cyclic, seasonal time occupies an important role in Kunitz's imagination (164). Examining the text from ecocritical perspective highlights the poem's environmental relevance and the poet's appreciation of the land and the natural laws.

The man is impressed by the insistence of an "indefatigable gull" which tries repeatedly to break a "piss-clam" by dropping it "on the rocks." Nature and its elements play an important role in working out the substance of the poem. He is as active as nature that pushes him to contemplate the bird which in turn provokes him to work.

The man begins making barriers around the garden in order to prevent the soil from drifting, and "gathering salt hay / in 
bushel baskets crammed to his chin" (11-12) to enrich the soil with seaweed and "peat moss and manure" (Kunitz \& Lentine 47). During summers, he is always watched "down in the tide marsh" (10) which invokes people to ask what he is doing there. Answering, he says:

"It is a blue and northern air," shiftings of the sky he says, as if the

had taught him husbandry. (13-15)

The natural world is depicted at a hinge point, at the time of seasons change. Kunitz appears aware of the cyclic seasonal time in relation to the vegetative world (Orr 164). His attempts to stop the garden's drifting and to fertilize its soil to make it valid for planting proves that he is "[. . .] mindful of his garden / which prepares to die" (20-21) because the "[..] blue and northern air" (13) foretells the coming of winter(season of death).

The man's closeness to the natural world and the "shiftings of the sky" have taught him "husbandry." Nature and man are affected by each other alternatively. To cultivate the garden, he keeps modifying it to create a conducive environment but the nature/climate of the region determines what kinds of plants should be instilled. Though not forcing, he goes on testing the adaptability of plants in the garden to know which can cope with the weather there (Kunitz \& Lentine 48). The significance of widening greenery and ethical treatment of the land are crystallized throughout the poem. Aldo Leopold's concept "The land ethic" "advocates nature preservation" (Buell 101). In the same concept, as J. Baird Callicott mentions in his essay "The Land Ethic Today", Leopold writes:

A land ethic [..] reflects the existence of an ecological conscience, and this in turn reflects a conviction of individual responsibility for the health of the land. Health is the capacity of the land for self renewal. Conservation is our effort to understand and preserve this capacity. (45)

Apparently, Kunitz respects the land which is assured in his conversation with Genine Lentine in The Wild Braid (2005) when he says:

It is imperative for any gardener to respect the land before alterations, modifications, or plans for the design of the garden are made. If a garden does not fit into that landscape and reflect it in some way, it is an invasion, an occupation. (50)

Though gardening is a tiresome work, the bird's insistent attempts inspire the man to go on converting his barren land into a flowering garden. "The wisdom of repetition in regard to the hard things is a lesson the natural world teaches" (Orr 32 ) as the subsequent lines indicate:

A man with a leaf in his head

gull

to break it open. watches an indefatigable

dropping a piss-clam on the rocks

Repeat. Repeat.

“"Try! Try!" clicks the beetle in his wrist, $(1-5,18)$

Motivated by what he sees, he begins imitating the bird.

Originally, man learns by imitation as it is clear in this poem. Meeker, in his essay "The Comic Mode," advocates Aristotle's concept of mimesis saying that "literature does imitate human actions" (Glotfelty and Fromm 155). Oscar Wilde, $19^{\text {th }}$ century playwright, suggested a significant modification to Aristotle's concept when he professed that "life imitates art at least as much as art imitates life" (166). A literary text is an imitation of life. By creating images of what life might be like, artists/writers and thinkers provide samples for human behavior that men might imitate. Reading literature modifies some of people's ideas about particular matters. Meeker assumes that, to a certain extent, "people can choose the roles they wish to play from among the many models preserved by literature and cultural traditions" (Ibid.). Then, reading could motivate them to adopt specific way of thinking and living. By imitating the bird, here, Kunitz would like his readers to imitate him. The 
poem indirectly proposes a way of contribution in solving an environmental problem. To encounter the suburban sprawl, people have to start planting arid lands to widen greenery that may probably bring balance about between human and nonhuman world.

Man's contribution, here, is governed by his property limits. The impact of his husbandry appears clearer on the microscale than the macro-scale. But, if all people take part in seeding parts of their personal properties, the cultivation effectiveness will undoubtedly surface on the macro-scale. The poet works on attracting the readers' attention to such solution that may largely increase the green areas.

However, it is an ecocentric poem affirms its poet's ecoconsciousness of the necessity of expanding verdancy not only erecting buildings. Kunitz emphasizes the belongingness of man to nature whose interconnected relationship proves their interchangeable impact. Therefore, Man has to minimize his unsustainable activities to preserve the environment. The poem elucidates man's responsibility to conserve nature and control his subversive acts by broadening green areas which serve as a counter balance to suburban sprawl.

\section{KUNITZ'S LATE POETRY: AN ECOCRITICAL READING}

Generally, ecocriticism evinces little interest in animals. The latter, however, is an ecocritical issue needs to be spotlighted because an anthropocentric thinking "turns all that is not human into an otherness subservient to human needs" (Estok 70). Thus, by positing such issue in literature, the poet provokes people to start thinking against anthropocentrism as an opposite polar of biocentrism.

Kunitz's "The Wellfleet Whale" was written in 1981 whilethe actual beaching of the whale took place in Wellfleet on September 12, 1966 (Kunitz 275). In this poem, the poet, as an observer/speaker addresses the whale telling it: "You have your language too" (1). Visualizing the whale within its normal habitatspeaking its own language without diminishing its animality by humanization emphasizes the poet's estimation of it.

The second and third sections are visual description of this hapless whale's environment (the harbor) retaining some of the auditory emphasis. The weather was sluggish. No sound is heard only that of the water clashing the shore and a lazy drift of gulls hovering overhead:

\section{It was the tag-end of summer. mouth}

We cheered at the sign of your greatness your head
From the harbor's you coasted into sight,

when the black barrel of erupted, ramming the water, (26-28, 32-34)

Seemingly, it is the whale's last summer. The greatness of the whale delights its viewers. Describing its head as a "black barrel" may bring to the mind the idea of a barrel of oil. In "The War Against the Trees", the bulldozers are hacking the ground seeking oil. The "black barrel," here, reignites the reader's mind of Man's devastation of nature and harming its living creatures (like the mole) for his personal interest. Thus, seeing the head like a "black barrel" marks humans' gourmand look of this creature (as one of profitable resources of nature) and foreshadows its pitiful situation in the human context in the fourth section. The poet, from "The War Against the Trees" to "The Wellfleet Whale", moves from the earth to the sea reporting the destruction of another site in the kingdom of nature (Al-Zwelef 130).

In this biocentric poem, the whale is seen as part of a greater biotic community occupying its own place without being underestimated by a human feature. Ecocritically, the poem centralizes the nonhuman elements (whale, gulls, the sea, the sky) and pushes the human, exemplified as an observer/speaker throughout the first three sections, to the edge. However, the appearance of man in the coming section asserts that his interest is above nonhuman objects'. People consider the whale as one of nature beneficial resources. Beached, the whale moves from its context to the human context where tragic things are 
expected.

The fourth section begins with: "There came a boy and a man / and yet other men running, and two / schoolgirls in yellow halters" (61-63) and others. The trouble starts as people come running to congregate around a huge whale crushed by its weight heaving deeply in the shoal. Impressed, they feel "awe and wonder" (54) at once. While they are waiting for the Curator of Mammals to come to take a sample of its blood:

Somebody had carved his initials souvenirs

a membrane thin as paper. $(82-85)$ in your flank. Hunters of had peeled off strips of your skin,

"Somebody" could be a tourist who "carved his initials" on its flank. Others, like hunters, slice pieces of its skin while this entirely helpless whale is still alive. Dying, the whale experiences what merciless, pitiless creatures are humans. This situation reveals humans' rooted distorted perceptions of themselves in relation to animals: their "self-flattering but vacuous sense of superiority and privilege, isolation" (Malamud 46). Humans' vanity causes a vast spectrum of harm to nonhuman objects. They find themselves in a historically unprecedented hegemonic position that authorizes them to savagely and ruthlessly abuse and unsustainably utilize nonhuman others and natural resources.

This whale groans under the humans' sharp knives without being paid attention to its misery. Ecocritically, the poem conveys a picture of the materialistic exploitive relation and interaction between man and nature. Most of humans' activities are noxious whether they are direct like hunting or indirect like tourism. Tourism is a cultural mask for a different kind of nature utilization. It is established for mankind's entertainment at the expense of other species. The poem portrays humans' inhumane actions. Humans and nonhuman elements co-exist in one greater biotic community connected by pragmatic relationship due to Man's anthropocentric way of thinking that underlines the significance and ascendency of their interest above that of nonhuman others.

The poem ends bitterly by the poignancy of this apostrophe in which, speaking to the whale, the poet says:

Master of the whale-roads, gulls

You have become like us, (134-138) let the white wings of the spread out their covers.

disgraced and mortal.

The poet calls upon the gulls to spreads their white wings as a cover over the whale or may be as a coffin because the whale has become as "disgraced and mortal" as human. The last line of the poem may remind the reader of "Robin Redbreast" when the bird is, like human, thrown out of Eden and condemned with mortality. All were "delivered to the mercy of time" (133). All are condemned with suffering and mortality in this world and the cause behind that is Man. Greg Garrard in his Ecocriticism (2004) says that "humans are either totally excluded from the scene, or introduced in one of two roles: destroyers or saviours" (152). John Felstiner, in his Can Poetry Save the Earth (2009), affirms that the mankind's carelessness has always angered Kunitz. Their carelessness is seen in the current poem and in "The War Against the Trees" when he sees "the bulldozers, drunk with gasoline" (3) attack "The great-grandfathers of the town /And with each elm a century went down" (9, 12) (208). (Italics mine)

The poem, based on an actual event, displays only a sample of a larger real problem happens around the world. The eerie song or language of this poem may not appeal to Japan, for instance. The country that every year "Kills fifty humpbacks with their incredible songs, plus hundreds of whales from other species, for "scientific research" (Felstiner 206). They have recently resumed their activity. David Wood, a professor of philosophy, in his article "What is Ecophenomenology?", says that the deep ecologists are comprehensibly worried about the lacuna between the collective consequences of humans' individual actions on the biosphere and their understanding, whether individual or collective, of the effect that they are causing. What can be seen in the surroundings is only an aspect or part of what really happens on the larger scale since: 
[What] we each experience [is] only a part of the earth [. . .] If my tree is dying, I notice. But the earth is dying, slowly, is not obvious, not something I can see at a glance out of my window. So, there is a gap between what I can see and what may really be happening. (93)

Collectively, Man's ecologically unsustainable deeds wind up in bad ramifications that may create a crisis. Such ecocentric/ecoconscious text enhances the public awareness of mankind's impact on the natural world. At the end, as Glen A. Love, in his "Revaluing Nature", asserts "much western American literature is an implicit plea for ecological awareness and activism" (Glotfelty and Fromm 230) which affirms the poet's ecoconsciousness.

Explicatively, the text discusses environmental issues addressed in the study of history and ethics. Perhaps, indirectly, the historical victimization and maltreatment of animals at the hand of Man is pinpointed. Kunitz is conscious of such issues especially the specific species extinction as a result of an unsustainable exploitation. Ethically, the poem offers two attitudes. The first one is that of the observer's/speaker's estimation of his fellow creature. He also realizes that they consist part of the biotic community. The other is that of people who congregated around the stranded whale. Carving their initials on the whale's flank and peeling it alive reflect people's avarice and the harmful merciless relationship links them to animals. Though what this poem posits is a sample of what is really happening in the real world, "the death of an individual is also the death of its kind" (Garrard 156). A glance is a ripe of education and the principal task of ecocriticism is to upgrade or to work on upgrading people's consciousness concerning such issues. People "must accord nonhuman animals more respect and develop a deeper sense of their integrity, their wisdom and importance on their own terms _ not as judged by the criteria of human utility or aesthetics" (Malamud 43). To solve environmental crises or issues, people, disavowing their anthropocentrism, should think locally and act globally.

Kunitz's Cape Cod garden can be seen as a minimized world of the real one. He is never far from "the creature world" around him (Felstiner 209). The spruce in his garden were the host of a whole family of a garden snakes which become the origin of the poem "The Snakes of September" (Kunitz and Lentine 53).

The snakes are depicted during a transitional period; from summer (season of life) to winter (season of death). When the days grow cooler, they are anticipated to become more and more lethargic. An ecocritical reading of the text centeralizes human and nonhuman elements in this poem. Man receives the impressions initiated by snakes here. The poem denotes Kunitz's knowledgeableness of their habits during different seasons.

Taking shelter in his Cape Cod garden, a couple of snakes:

appear on show

dangling head-down, entwined

$(18,22-23)$ in a brazen love-knot.

Entwined, they appear dangling from the top to the bottom of the tree looking for the warmth of the sun. Man is responsible of his environment and its guests as well. He treats them kindly by putting his "hand and stroke / the fine, dry grit of their skins" (24-25). The stroke signifies the friendly relation binds man with his fellow creatures. As an ecocentric poem, it focuses on the relationship and interaction between them. Kunitz's relationship with animals and plants can transact without language. For him, there are various forms of communication other than language: "the warmth of one's body is a form of communication. The stroke of one's hand is a means of communication" (Kunitz and Lentine 53). He can get into contact with the natural world through different ways. He finds comfort and solace in nature, and in his bad times, his fellow creatures sustain him (Felstiner 209).

The sort of connection between human and nonhuman others, portrayed in such domesticated natural environment, polarizes the reader's interest. Such biocentric poem enlightens him of the interrelated relation that connects creatures in a greater biotic community embraces them all. The concept of community is extended by Leopold to "'include soils, water, plants, animals': a 'biotic community' in which humankind is 'one of thousands of accretions' and species are entitled to 
existence 'as a matter of biotic right"' (Buell 100). As partners, their occupation a place in this world is a matter of right. At the end of the poem, Kunitz moves from the particular to the universal acknowledging that:

\author{
After all, \\ land, \\ At my touch the wild \\ trembles. (26-31)
}

\author{
we are partners in this \\ co-signers of a covenant. \\ braid of creation
}

The poet realizes humans and nonhuman others' partnership on this planet. "The wild braid of creation" may, literally, refer to the entwined dangling snakes and, metaphorically, the relation binds all creatures. It is a braid whose quiffs are closely interrelated. In the "braid of creation," one can not be defined alone without taking into consideration his place and relationship with the physical environment and/or nonhuman life forms (Buell 101). Everything is interconnected, entwined like the two snakes. Ecoconsciously, Kunitz wants to enflames the reader's/people's consciousness of "'the relational, total field-image' of 'organisms as knots in the biospherical net or field of intrinsic relations"' (qtd. in Buell 102), i.e., knots within "the wider systems of Nature" (104). Thus, animate and inanimate organisms are like interrelated knots in a net; a "brazen love-knot."

Indeed, the text deals with issues of a philosophical nature. Kunitz acknowledges explicitly and directly the interconnectedness relationship among creatures of different species. They shape the "braid of creation" whose trembling whether positive or negative relies on Man's activities' conservative and sustainable dimensions.

Aware of the truth of the partnership and simultaneous interchangeable impact among creatures, in every encounter he has with animals in the imagination or in the flesh, Kunitz attempts to "atone for our past record and to seek a better path for the future" (Malamud 43). Kunitz's advocate of animal treatment enhancement affirms his environmental ethics and his possession of ecological conscience. For the survival's sake, humans and nonhuman objects should do good to each other. Kunitz likes to feel that "one's family extends across the borders of the species and belongs to everything that lives" (Kunitz and Lentine 54).

The poem as an ecoconscious text shows the importance of the biocentric outlook on nature which emphasizes the poet's seeking the welfare of all species. The ecocentric poem's significance assures the poet's ecoconsciousness who purports to intensify people's awareness through art. William Rueckert in his essay "Literature and Ecology" says that "[e]very poem is an action which comes from a finely developed and refined ecological conscience and consciousness" (Glotfelty and Fromm 116).

In "The Snakes of September", Kunitz advocates an ecological coexistence among organisms as the one he saw in his poem "Nocturne". Life is interconnected on this earth as Neil Evernden affirms in his essay "Beyond Ecology" by saying that all organisms communities can co-evolve. All of them are literally interrelated (Glotfelty and Fromm 95). Kunitz longs to enlighten people and stir their consciousness toward such an insight. Thus, his poem works on the consciousness which is a primary task of ecocriticism. Being ecologically enlightened, Kunitz's poetry can be regarded, like what Leonard Scigaj terms, as "sustainable poetry" for it deals with humans' relation to the natural world (qtd. in Malamud 61).

\section{CONCLUSION}

To conclude here, ecocritically, the study has analyzed the textualized eco-issues in the chosen poems highlighting actual problems happen nowadays. Like ecocentric and biocentric poems disclose itswriter's deep consciousness of the planet ecosystem slow deterioration due to mankind's unsustainable acts.Kunitz posits suburbanization as an actual contemporary environmental problem in "The War Against the Trees", and proposes, indirectly, in "The Mulch", expanding verdancy as a concrete effectual solution to bring balance about between human and nonhuman world. "The Mulch" itself is ecopraxical text, and, quite possibly, Kunitz's whole work, if it is regarded as one text, is ecopraxical text. In "The Wellfleet Whale", he discusses animal victimization and abuse issues. "The Snakes of September" gives a direct but abstract solution by setting 
straightforward acknowledgementof animals as partners of humans on this planet that challenges/dismantles the anthropocentric foundations upon which humanities are built. Accordingly, the mentioned poems have theoretical and practical side concerned environmental issues.

These poems offer a practical framework for reconsidering and rebuilding our relationship with nature. They assures ecocriticism's plea for ecological awareness. Definitely, such poems are generated from a refined ecological conscience and consciousness. They confirm the ecopraxicality of Kunitz's text and his developing ecoconsciousness.

\section{WORKS CITED}

Al-Zwelef, Kawther Mahdi. "Nature in Some of Stanley Kunitz's Poems.” American International Journal of Contemporary Research 4.4 (2014): 127-134. Print.

Buell, Lawrence. The Future of Environmental Criticism: Environmrntal Crisis and literary Imagination. Malden, MA: Blackwell, 2005. Print.

Callicott, J. Baird. “The Land Ethic Today.” Topoi 12.1 (1993): 41-51. Print.

Dobie, Ann B. Theory into Practice: An Introduction to Literary Criticism. $3^{\text {rd }}$ ed. Australia: Wordsworth Cengage Learning, 2012. Print.

Estok, Simon C. "Theory from the Fringes: Animals, Ecocriticism, Shakespeare." Mosaic: An Interdisciplinary Critical Journal 40.1 (2007): 61-78. Print.

Evernden, Neil. "Beyond Ecology: Self, Place, and the Pathetic Fallacy." The Ecocriticism Reader: Landmarks in Literary Ecology. Ed. Cheryll Glotfelty and Harold Fromm. Athens: U of Georgia P, 1996. 92-104. Print.

Felstiner, John. Can Poetry Save the Earth?: A Field Guide to Nature Poems. New Haven: Yale UP, 2009. Print.

Garrard, Greg. Ecocriticism. London: Routledge, 2004. Print.

Glotfelty, Cheryll. "Introduction: Literary Studies in an Age of Environmental Crisis." The Ecocriticism Reader: Landmarks in Literary Ecology. Ed. Cheryll Glotfelty and Harold Fromm. Athens: U of Georgia P, 1996. xv-xxxvii. Print.

Kunitz, Stanley, and Genine Lentine. The Wild Braid: A poet Reflects on a Century in the Garden. New York: Norton, 2007. Print.

Kunitz, Stanley. Selected Poems 1928-1958. Boston: Atlantic-Little, Brown, 1958. Print.

---. The Collected Poems. New York: Norton, 2000. Print.

Love, Glen A. "Revaluing Nature: Toward an Ecological Criticism." The Ecocriticism Reader: Landmarks in Literary Ecology. Ed. Cheryll Glotfelty and Harold Fromm. Athens: U of Georgia P, 1996. 225-240. Print.

Malamud, Randy. Poetic Animals and Animals Souls. New York: Palgrave, 2003. Print.

McDowell, Michael J. "The Bakhtinian Road to Ecological Insight." The Ecocriticism Reader: Landmarks in Literary Ecology. Ed. Cheryll Glotfelty and Harold Fromm. Athens: U of Georgia P, 1996. 371-91. Print.

Meeker, Joseph W. "The Comic Mode.” The Ecocriticism Reader: Landmarks in Literary Ecology. Ed. Cheryll Glotfelty and Harold Fromm. Athens: U of Georgia P, 1996. 155-69. Print. 
Mishra, Sandip Kumar. "Ecocriticism: A Study of Environmental Issues in Literature." BRICS Journal of Educational Research 6.4 (2016): 168-70. Print.

Oppermann, Serpil. "Theorizing Ecocriticism: Toward a Postmodern Ecocritical Practice." Interdisplinary studies in Literature and Environment 13.2 (2006): 103-128. Print.

Orr, Gregory. Stanley Kunitz: An Introduction to the poetry. New York: Columbia UP, 1985. Print.

Phillips, Dana. "Ecocriticism, Literary Theory, and the Truth of Ecology.” New Literary History 30.3 (1999): 577-602. Print.

Rueckert, William. "Literature and Ecology: An Experiment in Ecocriticism." The Ecocriticism Reader: Landmarks in Literary Ecology. Ed. Cheryll Glotfelty and Harold Fromm. Athens: U of Georgia P, 1996. 105-123. Print.

Thomason, Elizabeth, ed. Poetry for Students: Presenting Analysis, Context, and Criticism on Commonly Studied Poetry. Detroit: Gale Group, 2001. Print.

White, Lynn. "The Historical Roots of Our Ecological Crisis." The Ecocriticism Reader: Landmarks in Literary Ecology. Ed. Cheryll Glotfelty and Harold Fromm. Athens: U of Georgia P, 1996. 3-14. Print.

Wood, David. "What is Ecophenomenology?” Research in Phenomenology 31.1 (2001): 78-95. Print. 